\title{
The Effectiveness of Bhumi Merapi Agrotourism Promotion through Instagram
}

\author{
Esti ${ }^{1)}$ Sunarru Samsi Hariadi ${ }^{2)}$ Alia Bihrajihant Raya ${ }^{3, a)}$ \\ 1,2,3 Study Program of Agriculture Guidance and Communication, Department of Agriculture Social Economy, \\ Faculty of Agriculture, Universitas Gadjah Mada \\ a) author correspondence: alia.bihrajihant.r@ugm.ac.id
}

DOI: https://doi.org/10.18196/jkm.122043

Article Info

Article history:

Received 21 Apr 2020

Revised 30 Okt 2020

Accepted 23 Nov 2020

\section{ABSTRACT}

Agrotourism is an activity that integrates the agricultural system and the tourism system so that it forms an attractive tourist attraction. In its development, an agrotourism needs to get support in the form of promotion to inform the public about agrotourism, to increase the number of visitors, to increase agricultural education to visitors and the income for agro-tourism managers. This research was conducted at Yogyakarta Bhumi Merapi Agrotourism and its aim is to identify the effectiveness of promotional medium for Bhumi Merapi Agrotourism by Instagram and the influencing factors. The method used was descriptive method with a quantitative approach. Sampling was done by systematic random sampling with a total of 61 respondents. The analysis used was the proportion test and multiple linear regression test. The results showed that effectiveness of promotion of Bhumi Merapi Agrotourism by Instagram was $95.08 \%$. It means that in general visitor rate Bhumi Merapi Agrotourism as an effective media for promotion. The effectiveness of Instagram is significantly influenced by the perception of visitors and the attractiveness of photos or videos which are uploaded on the official Instagram account of Bhumi Merapi Agrotourism.

Keywords: Agrotourism; Bhumi Merapi; Instagram; Promotion

\section{ABSTRAK}

Agrowisata merupakan suatu kegiatan yang mengintegrasikan sektor pertanian dengan sektor pariwisata sehingga membentuk objek wisata yang menarik. Pada pengembangannya, suatu agrowisata perlu mendapatkan dukungan dalam bentuk promosi untuk mengenalkan kepada publik, meningkatkan banyaknya jumlah pengunjung, menambah edukasi kepada pengunjung serta menambah pemasukan bagi pengelola agrowisata. Penelitian ini dilaksanakan di Agrowisata Bhumi Merapi Yogyakarta dengan tujuan mengetahui tingkat keefektifan promosi Agrowisata Bhumi Merapi melalui Instagram dan faktor-faktor yang mempengaruhi. Metode yang digunakan yaitu metode deskriptif dengan pendekatan kuantitatif. Pengambilan sampel dilakukan secara systematic random sampling dengan total responden 61 orang. Analisis yang digunakan yaitu uji proporsi dan uji regresi linier berganda. Hasil penelitian menunjukan keefektifan promosi Agrowisata Bhumi Merapi Yogyakarta melalui Instagram sebesar 95,08\% artinya, secara umum pengunjung menilai promosi Agrowisata Bhumi Merapi melalui Instagram efektif. Keefektifan Instagram secara nyata dipengaruhi oleh persepsi pengunjung dan daya tarik foto/video yang diunggah pada akun resmi Instagram Agrowisata Bhumi Merapi.

Keywords: Agrowisata; Bhumi Merapi; Instagram; Promosi 


\section{INTRODUCTION}

Agriculture sector has important and strategic role in supporting economy. It is because agriculture sector can give job field for the people in villages and provides food. The advancement of agriculture sector is supported by development of agriculture technology used by the agriculture actors. The activity of sharing the agricultural information/ technology is known as agricultural extension (Sadono, 2008). Agriculture extension can benefit technology in program socialization. The role of agricultural mentor is as facilitator and consultant that can help the member of the society to have process of changes in terms of knowledge, attitude and skill (Saputri et al., 2016). The change of knowledge is obtained from the visit in a place like nature tourism or tourism in agricultural field.

Media that shares information rapidly and widely really supports the process of agrcultural counseling. Media is a part of mass communicatikon that has characteristics such as: the nature of the message is open for public, it varies from the aspects of age, religion, tribe, work or needs (Cangara, 2009). The mass communication nowadays is various, and one of its ways is done through social media. The development of social media is caused by the behaviour of the people in the digital era that experiences very rapid change (Supradono \& Hanum, 2011). Social media is a media that offer digitalizaton, convergence, integrity, and development of networking related to the production and the delivery of the message (Watie, 2016).

Social media that has a good message will give a good impression as well. A message will give significant influence for anyone who reads it. Hilderandt in (Kusumastuti, 2009) states that the 7C elements in a communication consist of completeness, conciseness, concrete, consideration, clarity, courtesy, and correctness. 7C elements in a communication affect the message delivered. Meanwhile, effective message is a message that can influence its readers to buy a product or service offered by the writer of the message.

The information or message delivered to someone makes the individual related to it develop a perception. It is started from the selection or filter and then the information entered is arranged to be a meaningful unity. Finally, the interpretation occurs on the fact of the entire information. The perception of a person is influenced by his perspective on certain condition, fact or act (Yani, 2009). There are three mechanisms in perception formation, namely: selectivity, closure, and interpretation. Selectivity is a condition in which a person is faced with stimulus or situation. It is usually in the form of close and direct sensing or in thorough sociocultural and physical form of the stimulus. Closure is a phenomenon that looks like physical mechanism to hear or to see, then to process and to absorb information. Interpretation is a process of interpreting on information or stimulus. It can also be defined as cognitive aspect of perception that is very significant because this process depends on the intensifying way, motivation, and personality of someone in which they are different from one another when facing information or stimulus.

According to wearesocial.com, Instagram belongs to the 10 most popular social media application used in Indonesia. Instagram is an application used to share photo and video that enables the user to take photo and video, to apply digital filter on them, and to share them to various social network services. Instagram was founded in 2010 by Kevin Systrom and Mike Krieger (Mahendra, 2017). The information shared through agrotourism Instagram is in the forms of photos and videos related to the agriculture activities and education in an agrotourism. The information that is accessed through Instagram with its searching feature is in accordance with the needs and can be accessed anytime by someone who needs it.

The development of technology can open opportunities to create newly innovative works and trends to earn income (Anwar, 2019). One of the ways to benefit social media is to use it as promotion media of a product, service or tourism. International Ecotourism Society states that Indonesia has been identified as a country that is prospective to develop tourism especially ecotourism (Junaedi \& Utama, 2017). It is proven by the high number of flora and fauna, wild animals, nature scenery, and mountains in Indonesia.

Bhumi Merapi Agrotourism is agrotourism that benefits the natural resources in Indonesia to become educational media and tourism for the visitors in the slope area of Mount Merapi in Yogyakarta. Bhumi Merapi Agrotourism needs to get support in the form of promotion to enhance the number of visitors and their awareness to save the beauty of its nature, to implement the agricultural education, and to increase the income. The promotion through Instagram has some strengths and one of them is that the majority of Instagram users have been already technologically literate. It means that they who are active users of Instagram are also the active ones in the other kinds of social media 
such as Twitter and Facebook. The promotion through Instagram can be done in accordance with the need and wish of the agrotourism manager and it is free of charge. So, it eases the owner. Besides, people usually look for the information through hashtags on tourism in Instagram such as \#agrotourism, \#naturetourism, \#jogjatourism, and the like (\#agrowisata, \#wisataalam, \#wisatajogja).

Agrotourism promotion is done in many ways such as reportage through local television broadcast, brochure, cooperation with travel agent, and local radio station. Meanwhile, the promotion that is actively done is the promotion through Instagram. The effectiveness level of the promotion through Instagram can be feedback or evaluation for the manager of Bhumi Merapi Agrotourism. Based on the background, the researcher is interested in finding out the promotion effectiveness level of Bhumi Merapi Agrotourism through Instagram and the factors that influence it.

\section{METHODS}

This research used descriptive method by giving description to the readers as clear as possible. The data collection used survey technique by using questionnaire as aid tool in order to convey the correlation among variables through hypothesis. The data analysis process in this research consisted of regression test and multiple linear regression test. The research was carried out in February - July 2019 in Bhumi Merapi Agrotourism in Yogyakarta.

The sample taking method in this research was systematic random sampling. It is a system of sample taking conducted by using certain interval consecutively. The method was applied to take the data of Bhumi Merapi Agrotourism visitors who have used its service. The number of the visitor taken was 61 people. The sample of the visitor was taken by waiting for the visitors who have finished enjoying Bhumi Merapi Yogyakarta once in every 30 minutes in the exit way and in the rest facility.

\section{RESULT AND DISCUSSION}

\section{The Effectiveness of Instagram Account of Bhumi Merapi Agrotourism as Promotion Media}

Bhumi Merapi Agrotourism has been developed since 2010. Dr. Wagimin was the founder of Bhumi Merapi Agrotourism located in Kaliurang Street Km 20 Sawungan Hamlet, Hargobinangun Village, Pakem Sub- District, Sleman Regency Yogyakarta Special Region. In the beginning of its establishment, in 2010 Bhumi Merapi Agrotourism focused on animal farm and agriculture. The agriculture developed was vegetable cultivation such as chili, tomato, bitter melon, and collard. Besides, herbal plants were also developed such as curcuma, red ginger, zingiber officinale (jahe gajah), turmeric, and other herbal plants. There was also the cultivation fruit rarely found in Yogyakarta, namely plantains. Meanwhile, the fishery focused on fish cultivation with pond (tambak) system like goatfish, catfish, parrot fish, and other kinds of fish.

Bhumi Merapi Agrotourism was considered as less profitable if it only managed animal farm and agriculture. Therefore, in 2015 Bapak Wagimin started combining the aspects of agriculture, animal farm, technology implementation in educational way, and tourism. It was marked by the additional facilities like outbound training, camping ground, Panggolo Cave tourism, and some animal park tourisms. Since 2016, Bapak Ismet has been the leader and he has focused on the development of agrotourism until now. One of the efforts carried out by the management so that many people knew about Bhumi Merapi Agrotourism was doing promotion through Instagram. Bhumi Merapi Agrotourism has vision and mission as follows:

\section{Vision}

Becoming a big tourism company that has basis in animal farm and agriculture with integrated farming, and having rural insights that has education characteristic for society. Putting forward local culture potentials that benefit for society and country. 


\section{Mision}

1. Building agrotourism that has basis in animal farm and organic agriculture combined with the natural surroundings.

2. Building business units in animal farm and agriculture that can be independent and is as used tourism destination by putting education forward.

3. Implementing efficient technology in all lines in Bhumi Merapi Agrotourism area.

4. Increasing and maintaining the service with characteristic of prioritizing cleanliness, safety, and comfort.

5. Creating human resource full of dedication and high loyalty to the company.

6. Collaborating with the society in the surroundings in building and developing Bhumi Merapi Agrotourism.

7. Cooperating with the government in agriculture, animal farming, and tourism in developing Bhumi Merapi Agrotourism.

Bhumi Merapi Agrotourism has facilities that function to attract and support tourism activities. The facilities can be the alternative way for the manager to earn additional income beside the entrance ticket. Meanwhile, the facilities provided in Bhumi Merapi Agrotourism are: tourism guide, pemandu, Jamnapari goat (kambing ettawa) park, rabbit park, reptile park, flower park, hydroponics and biogas, horse riding, camping ground, outbound area, attraction signpost, souvenir shop, toilet and canteen, handwashing sink, and praying room (mushola). According to (Malkanthi \& Routry, 2011), the activities in the agrotourism vary from simple agriculture visit to the complex one such as educational program, recreation or amusement including bed and breakfast, and staying time around the farmland. It can be the material to do promotion so that the interest of the people to visit gets increasing.

Instagram account of Bhumi Merapi Agrotourism was created in December 2015 and it has been active until now. The administrator of the Instagram account always updates the information such as the activities, facilities, and opening hours through the official Instagram account of Bhumi Merapi Agrotourism every day. It is because the manager wants to build the image on education and agrotourism activities. The promotion of Bhumi Merapi Agrotourism has ever been done through the reportage like Laptop si Unyil Trans7, news in TVOne, NetTV, and Jogja private television. In the beginning of the agrotourism establishment, the promotion has ever been done through newspaper and local radio stations in Jogja. It was in order to introduce the agrotourism to many people so that they were interested to visit.

The effectiveness of the promotion of Bhumi Merapi Agrotourism through Instagram is a comprehension received by Instagram users towards the message delivered through the Instagram account of Bhumi Merapi Agrotourism. The comprehension measured includes three aspects namely knowledge, attitude, and behavior. It is because the comprehension of the target on the message and how far the accuracy of the stimulus reception in accordance with what is expected by the message sender becomes the benchmark of mass communication effectiveness. The information or message comprehension in the communication process is one of the effects of communication. The effect is the changes inside the audience because of media message exposure. According to LionBerger \& Gwin in (Marlina et al., 2009), there are three kinds of effect of communication produced by the exposure towards the message of mass media, namely cognitive, affective, and behavior effects. Inayah (2011) in (Fadhila et al., 2017) also mentions that the effects that occur in mass communication are cognitive, affective, and behavior. The knowledge aspect is indicated by the increasing knowledge on Bhumi Merapi Agrotourism through Instagram. The affective aspect has the characteristic of the change and building of attitude after accessing Bhumi Merapi Agrotourism Instagram account. Meanwhile, behavior aspect is indicated by action as the result of attitude change accepted by the receiver of the information from Bhumi Merapi Agrotourism Instagram account. The three aspects can be elaborated through some statements in Table 1.1 entitled the Effectiveness Level of Bhumi Merapi Agrotourism Promotion through Instagram. 
Table 1.1. The Effectiveness Level of Bhumi Merapi Agrotourism Promotion through Instagram

\begin{tabular}{|c|c|c|c|c|c|}
\hline No. & Indicator & $\begin{array}{c}\text { Score } \\
\text { Interval }\end{array}$ & $\begin{array}{c}\text { Average } \\
\text { Score } \\
\end{array}$ & $\begin{array}{c}\text { Effectiveness } \\
\text { Level }(\%) \\
\end{array}$ & Category \\
\hline \multicolumn{6}{|c|}{ A. Knowledge } \\
\hline 1 & $\begin{array}{l}\text { Promotion using Instagram media of } \\
\text { Agrotourism Bhumi Merapi is } \\
\text { effective in increasing knowledge } \\
\text { about natural tourism activities }\end{array}$ & $0-5$ & 4.15 & 82.95 & Very high \\
\hline \multirow[t]{2}{*}{2} & $\begin{array}{l}\text { Promotion using Instagram media is } \\
\text { effective in increasing trust in the } \\
\text { information conveyed }\end{array}$ & $0-5$ & 4.05 & 80.98 & Very high \\
\hline & Average & & & 81.96 & Very high \\
\hline \multicolumn{6}{|c|}{ B. Attitude } \\
\hline 3 & $\begin{array}{l}\text { Promotion using Instagram media is } \\
\text { effective in making me have } \\
\text { memories of natural tourism activities }\end{array}$ & $0-5$ & 4.18 & 83.61 & Very high \\
\hline 4 & $\begin{array}{l}\text { Promotion using Instagram media is } \\
\text { effective in making me have } \\
\text { memories of flora (animal) education }\end{array}$ & $0-5$ & 4.07 & 81.31 & Very high \\
\hline \multirow[t]{2}{*}{5} & $\begin{array}{l}\text { Promotion using Instagram media is } \\
\text { effective in making me have } \\
\text { memories of flora (agriculture) } \\
\text { education }\end{array}$ & $0-5$ & 4.03 & 80.66 & Very high \\
\hline & Average & & & 81.86 & Very high \\
\hline \multicolumn{6}{|c|}{ C. Behavior } \\
\hline 6 & $\begin{array}{l}\text { Promotion using Instagram media } \\
\text { effectively made me want to return to } \\
\text { travel to Bhumi Merapi Agrotourism }\end{array}$ & $0-5$ & 4.05 & 80.98 & Very high \\
\hline \multirow[t]{4}{*}{7} & $\begin{array}{l}\text { Promotion using Instagram media is } \\
\text { effective in making me want to } \\
\text { recommend Agrotourism Bhumi } \\
\text { Merapi to friends or relatives }\end{array}$ & $0-5$ & 4.26 & 85.25 & Very high \\
\hline & Average & & & 83.11 & Very high \\
\hline & Average $(A+B+C)$ & & & 82.31 & Very high \\
\hline & Amount $(\mathrm{A}+\mathrm{B}+\mathrm{C})$ & $0-35$ & 28.79 & & \\
\hline
\end{tabular}

Source: Primary Data Analysis, 2019

The definition of "effectiveness" in this study is a state of acceptance and understanding of messages conveyed in communication through an Instagram media. The effectiveness can be seen from several indicators after accessing Bhumi Merapi Agrotourism Instagram, namely the cognitive aspect, affective aspect, and behavioral aspect. The cognitive aspect is marked by increasing knowledge about Bhumi Merapi Agrotourism. The affective aspect is marked by the formation of attitudes after the process of increasing knowledge of Bhumi Merapi Agrotourism, which is accessed by visitors through Instagram. The behavioral aspect is the final aspect which is marked by actions, behaviors, or activities after receiving information from Bhumi Merapi Agrotourism Instagram.

A proportion test can further determine visitors' level of effectiveness in using Instagram as a promotional medium. The steps for the proportion test are as follows:

a. Hypothesis test

Ho: $\mathrm{P} \leq 50 \%$

Ha: $\mathrm{P}>50 \%$

b. Hypothesis

Ho : It is estimated that less than $50 \%$ of visitors rate the effectiveness of Bhumi Merapi Agrotourism promotion through Instagram as high.

Ha : It is estimated that more than $50 \%$ of visitors rate the effectiveness of Bhumi Merapi Agrotourism promotion through Instagram as high. 
c. The level of significance (belief) at $\alpha=0.05,(5 \%), n=61$

d. Proportion test

$$
\begin{aligned}
& Z_{\text {count }}=\sqrt{\frac{\left(\begin{array}{l}
x \\
n
\end{array}\right)-P o}{\sqrt{\frac{P o(1-P o)}{n}}}} \\
& Z_{\text {count }}=\sqrt{\frac{\left(\begin{array}{c}
58 \\
61
\end{array}\right)-0.5}{\sqrt{\frac{0.5(1-0.5}{61}}}} \\
& Z_{\text {count }}=\sqrt[\frac{0.45}{0.06}]{Z_{\text {count }}=7.5}
\end{aligned}
$$

e. Testing criteria

$\mathrm{Z}_{\text {count }}>\mathrm{Z}_{\text {table }} \quad$ : Ho is rejected, Ha is accepted, so the hypothesis is accepted.

$\mathrm{Z}_{\text {count }} \leq \mathrm{Z}_{\text {table }} \quad$ : Ho is accepted, Ha is rejected, so the hypothesis is rejected.

f. Conclusion

$\mathrm{Z}_{\text {count: }} \quad 7.5$

$Z_{\text {table: }} \quad 1.64$

$Z_{\text {count }}>Z_{\text {table }}$, then Ho is rejected, while Ha is accepted, so the hypothesis is accepted.

The proportion test results a $Z_{\text {count }}$ value of 7.5. In comparison, the $Z_{\text {table }}$ is known to be 1.64 . This shows that the $Z_{\text {count }}$ value is greater than the $Z_{\text {table }}$ value obtained so that Ho is rejected, while Ha is accepted. The hypothesis proposed is accepted that is more than $50 \%$ of visitors rate that the effectiveness of Bhumi Merapi Agrotourism promotion through Instagram as high.

The results of this study indicate that the level of effectiveness of Bhumi Merapi Agrotourism promotion through Instagram is very high. It can be seen in Table 1.1 that the average percentage of the effectiveness of Bhumi Merapi Agrotourism promotion through Instagram is $82.31 \%$, and the highest average value is in the behavioral aspect, namely $83.11 \%$. Changes in one's behavior are the basis for determining the effectiveness of Instagram as a promotion media. In addition, the attitude and affective aspects also determine the effectiveness of Instagram as a promotion media. The behavior of visitors after accessing information from Instagram can be shared through invitations on Instagram to relatives or closest colleagues. In addition, the behavior of visiting and revisiting Bhumi Merapi Agrotourism is an indicator of the effectiveness of the promotion that has been carried out by the management.

Aspects of knowledge can be seen in the knowledge process that increases after accessing the Instagram of Bhumi Merapi Agrotourism. The knowledge aspect has a mean of $81.96 \%$. In Table 1.1, it can be seen that the promotion using Instagram of Bhumi Merapi Agrotourism is effective in increasing knowledge about natural tourism activities with an effectiveness level of $82.95 \%$. This is because the information displayed is in accordance with the needs of visitors and can be a reference for natural tourism which is located not far from the city center of Yogyakarta. In addition, the Instagram account of Bhumi Merapi Agrotourism displays information about children's educational tourism activities that can be an alternative for parents or teachers to introduce children to agriculture (flora and fauna) from an early age. The aspect of knowledge can also be seen in the second indicator, namely promotion using Instagram media effectively increases the belief in the information conveyed by an average of $80.98 \%$. This is because the information conveyed is not only limited to captions or photos of agrotourism locations, but also features photos or videos of the latest visitor activities and the excitement of the activities carried out so that it will increase visitors' trust. Photos of visitors' activities include the moment when the guide explains about reptiles, explains about hydroponics, during outbound games, field trips, biogas production training activities, and the process of making kopi luwak (civet coffee). The result that aspect of knowledge increases after accessing Instagram is in line with the research conducted by Sari ZA et al. (2019), which states that Instagram social media can be used as a health promotion media to increase public knowledge and attitudes to find out certain information.

Attitude aspects can be seen in the process of changing one's attitude after receiving information from the Agrotourism Bhumi Merapi Instagram. The knowledge aspect has a mean of $81.86 \%$. In Table 1.1, it can be seen that promotion using Instagram media is effective in making visitors have memories of natural tourism activities with an average of $83.61 \%$. This is due to the location of agrotourism which is at the foot of Mount Merapi so that visitors can clearly see Mount Merapi when the weather is clear and the air is cool. In addition, natural scenery can be a memory for 
people who have lived in cities for a long time or people who are tired of current urban conditions that still lack of open green spaces. The next indicator, promotion using Instagram media effectively makes visitors have memories of fauna education, which has an average of $81.31 \%$. This is because there are various rare animals such as alligator snapping turtles, Merino sheep, cobra snakes, water turtles, geckos, tortoises, iguanas, and salvator (a type of lizards). These various animals are a memory for children and adults who have never seen before. Memories of animal education can be seen from how to care for, clean cages, and feed animals. For example, feeding pythons with live chickens, and so on.

Promotion indicators using Instagram media effectively make visitors have memories of flora education (agriculture). This indicator has an average of $80.66 \%$. This is because Bhumi Merapi Agrotourism has land that is used to grow rice and various vegetables, such as long beans, corn, and chilies. In addition, there is a location for making biogas where the waste during the production of biogas becomes fertilizer for plants in Bhumi Merapi Agrotourism location. Aquaponics and hydroponics are attractive for visitors who want to grow crops on limited land. Memories can also be obtained by people who have often been active in nature and are only oriented towards results, not on education, let alone tourism, which can add value from the farming activities. Agricultural counseling packaged into an educational tour becomes an alternative as time goes by. For some people, studying agriculture is not an interesting thing because their view of agriculture is close to things that are dirty, smelly, and have uncertain results. However, with a little creativity, agriculture can be packaged more neatly, beautifully, and attractively because it is located in an agrotourism location and with social marketing that does not only expect from yielding crops.

Behavioral aspects can be seen in the action process as a result of changes and the formation of a person's attitude after receiving information from Bhumi Merapi Agrotourism Instagram. Behavioral aspects have a mean of $83.11 \%$. In Table 1.1 , it can be seen that promotion using Instagram media is effective in making visitors want to return to travel to Bhumi Merapi Agrotourism with an average of $80.98 \%$. This is because a good impression will make visitors have the desire to visit again or to explore more into new activities or places in Bhumi Merapi Agrotourism. The good impression between the promotion of the original conditions in the field is not much different. The friendly manager and guide's service can also make visitors return to travel to Bhumi Merapi Agrotourism. The next indicator is that promotion using Instagram media effectively makes visitors want to recommend Bhumi Merapi Agrotourism to colleagues or relatives with an average of 85.25\%. This is due to the benefits received by visitors after directly accessing and visiting Bhumi Merapi Agrotourism. Therefore, visitors will recommend to colleagues or relatives because the benefits obtained have been experienced firsthand when traveling to Bhumi Merapi Agrotourism.

The effectiveness of promotion through Instagram includes three aspects, namely knowledge, attitudes, and behavior. The delivery of information aims to increase knowledge and promotion carried out by the manager of Bhumi Merapi Agrotourism. Therefore, managers often update the latest information through photos/videos postings on Bhumi Merapi Agrotourism Instagram. The manager posts activities every day both in the Instagram story and posts on the homepage. Visitors will easily remember the information submitted and get information in the form of photos/videos uploaded. It is also clarified with an explanation of the information through captions. The information conveyed visually is easier to remember because it involves the eye sense organs that see a photo of the activity or atmosphere directly in a specific location. Agrotourism visitors get benefits, so they want to return to travel to Bhumi Merapi Agrotourism Yogyakarta. In addition, they also want to recommend it to friends or relatives. Determination of the attitude of visitors is based on increased knowledge and formation of good attitudes after accessing information through Bhumi Merapi Agrotourism Instagram. Lestari et al. (2019) convey that knowledge, attitudes, and behavior affect self-characteristics to do a job. This is in line with the manager's duties as a provider of information to visitors through Bhumi Merapi Agrotourism Instagram.

Based on the results of the effectiveness of Instagram as a promotion media, it is revealed that social marketing based on partnerships and policies affects the behavior and interests of the wider community that it becomes an alternative to agricultural extension through Bhumi Merapi Agrotourism. In addition, the existence of agrotourism development in the village community-based activities is expected to provide benefits for urban communities to better understand and give appreciation to the agricultural sector as well as become a means of education (Budiarti \& Muflikhati, 2013). This means that agricultural extension can be implemented through Bhumi Merapi Agrotourism Instagram, which is used effectively by the manager to display various kinds of 
information. However, the effectiveness of Instagram as a promotion media for Bhumi Merapi Agrotourism needs to be maintained and provided with innovations, for example conceptual posts in the promotion process through Instagram. In addition, it is to maintain existence amid increasingly fierce agrotourism competition.

\section{Regression Test on the Effectiveness Level of Bhumi Merapi Agrotourism Instagram as a Promotion Media}

The effectiveness level of Bhumi Merapi Agrotourism Instagram as a promotion media is thought to be influenced by several factors. These factors come from internal factors that are related to the characteristics of agrotourism visitors who have institutions. Meanwhile, external factors relate to Instagram which is managed by agrotourism in terms of completeness of information and attractiveness of posted photos/ videos. The analysis used is linear regression analysis which aims to determine how significant the independent variable affects the dependent variable. The Backward method is the method chosen in multiple linear regression analysis. This is because the Backward method at the initial stage displays the results of all variables. After that, the independent variables that do not have a significant effect on the dependent variable will be gradually eliminated. The dependent variable in this study is the effectiveness of Instagram as a media for promoting Bhumi Merapi Agrotourism, while the independent variables in question are age (X1), frequency of use of Instagram (X2), perceptions of Instagram (X3), completeness of information (X4) and attractiveness of photos / video (X5). The results of multiple linear analysis can be seen in Table 1.2.

Table 1.2. Results of Multiple Linear Regression Test Analysis Regarding the Factors Influencing the Effectiveness of Bhumi Merapi Agrotourism Promotion through Instagram (Model 4).

\begin{tabular}{clrrrr}
\hline No. & \multicolumn{1}{c}{ Variable } & Koef. Regression (B) & T Hit & \multicolumn{1}{c}{ Sig } & Ket. \\
\hline 1 & Visitors' perceptions on Instagram (X3) & 0.368 & 2.631 & 0.010 & $*$ \\
2 & Photo / video appeal (X5) & 0.365 & 1.966 & 0.014 & $*$ \\
\hline Constant & 10,303 & & & \\
\hline R Square & 0.338 & & & \\
Adjusted R Square & 0.316 & & \\
F Count & 14.384 & & & \\
\hline
\end{tabular}

Note: * Significance at 5\% level, NS: Non-significant

Source: Primary Data Analysis, 2019

Based on the last model of the Backward method that has been carried out, namely Model 4, the effectiveness of Bhumi Merapi Agrotourism Instagram as a promotion media is influenced by internal factors of visitors' perceptions on Bhumi Merapi Agrotourism Instagram (X3) and is influenced by external factors of photo / video attractiveness (X4). Further explanations regarding the factors that influence the effectiveness of Instagram as a promotion media for Bhumi Merapi Agrotourism Yogyakarta are as follows:

\section{The visitors' perceptions on Bhumi Merapi AgrotourismInstagram}

The process of forming perceptions in this study is measured from the aspects of selectivity, closure and interpretation of Bhumi Merapi Agrotourism Instagram. Based on the results of the multiple linear analysis test with the Backward method that has been carried out, the regression coefficient value is 0.368 with a significance value of 0.010 . The positive value of the regression coefficient shows that the variable perceptions of visitors to Bhumi Merapi Agrotourism Instagram with the effectiveness of promotion through Instagram go unidirectional, meaning that the better the visitor's perception of Bhumi Merapi Agrotourism Instagram, the more effective use of Instagram is as a promotion media. The significance value which is smaller than $\alpha(0.05)$ indicates that the variable of visitors' perceptions on Bhumi Merapi Agrotourism Instagram has obvious effect on Instagram effectiveness as a promotion media.

Based on the results of the multiple linear regression analysis, the hypothesis stating that the better the visitor's perception of Bhumi Merapi Agrotourism Instagram, the higher the effectiveness of promotion through Instagram is, is accepted. This is because the perception of visitors to Instagram of Bhumi Merapi Agrotourism is already good, meaning that visitors already have a good assessment of the Instagram managed by Bhumi Merapi Agrotourism. Instagram of Bhumi Merapi Agrotourism can 
fulfill the information needed by visitors and the general public, such as from activities to existing facilities at Bhumi Merapi Agrotourism.

In accordance with the results of research that has been done, the visitors have a very good level of perception, which is $81.05 \%$. The perception of visitors to Bhumi Merapi Agrotourism Instagram begins when visitors open the Agrotourism Instagram then do and see various information contained in Bhumi Merapi Agrotourism Instagram. Furthermore, visitors feel the benefits of increasing knowledge about reptiles, regarding various plants and their management innovations (aquaponics and hydroponics) and so on. The final perception formation is that visitors can choose tour packages, visit preferred spots, gain knowledge through posts made by the manager, the desire to travel again and recommend to colleagues or relatives.

The visitor's perception relates to the completeness of information based on 6C (completeness, conciseness, concrete, clarity, courtesy, and correctness). It can be seen that the results of the completeness of information obtained are high, which is $70.60 \%$, forming good perceptions as the result. Completeness of information will affect when visitors receive, digest and determine attitudes towards information after accessing Bhumi Merapi Agrotourism Instagram. The higher the information displayed, the better the visitor's perception of Bhumi Merapi Agrotourism Instagram. Good perceptions will affect the effectiveness of the promotion of Bhumi Merapi Agrotourism via Instagram. The successfulness of the promotion can be seen from the appropriate images of the information as seen in Bhumi Merapi Agrotourism Instagram photo or video posts.

The perception of visitors is also related to promotion (social marketing). The fundamental difference between commercial promotion and social marketing is partnerships and policies that affect the behavior and interests of the wider community for consideration. The formation of visitor perceptions can be formed due to memories after accessing Bhumi Merapi Agrotourism Instagram. Educational information such as fun facts related to flora and fauna are needed by the community, potential visitors or visitors who do not go around as a whole in Bhumi Merapi Agrotourism. This can be used as interesting information as well as a material consideration for the wider community to visit, to come back on tour or to recommend to friends or relatives about Bhumi Merapi Agrotourism.

The results of this study are in line with the results of research conducted by (Kurniawan, 2015) who found that perceptions affect the effectiveness of Instagram as a promotion media. Perception is an aspect of psychology where visitors have responses related to Instagram accounts that are used to promote a tourist object and also to the tourist attraction itself. Rangkuti (2009) explained that everyone will have a perception of an object because of the three perceptual processes, namely selective attention, selective distortion, and selective memory. Visitors to Bhumi Merapi Agrotourism Yogyakarta Instagram who access Bhumi Merapi Agrotourism Yogyakarta Instagram have obviously gone through three perceptual processes. Kurniyati \& Rahmawati (2018) in the research on tourist perceptions of Instagram also stated that information in the form of photos submitted by Instagram accounts can shape the perception of Instagram users as potential tourists to make decisions to visit a tourist spot. Thus, visitor perceptions have a significant effect on the effectiveness of promotions via Instagram.

\section{Photo/ video appeal}

Instagram is a social media that relies on the appearance of photos and videos to be shared with other Instagram users. The attractiveness of photos / videos on Instagram is of great concern to those who use it as a promotion media. Based on the results of the multiple linear analysis test, the regression coefficient value obtained is 0.365 with a significance value of 1.966 . The positive regression coefficient value shows that the variable of photo/ video attractiveness with the effectiveness of Instagram as a promotion media goes in the same direction, meaning that the more attractive the photos/ videos are, the more effective the use of Instagram will be as a promotional medium. The significance value which is less than $\alpha(0.014)$ indicates that the photo/ video attractiveness variable has a significant effect on the effectiveness of Instagram as a promotion media. This is due to a moderate level of interest in the art of photography or videography, which means that the uploaded photo/ video is nothing special. In addition, people who often use Instagram to find information on agrotourism will have more experience so that they can be used to compare photo/ video posts so that some visitors think that posts on Bhumi Merapi Agrotourism Instagram are less conceptual. However, the posts always contain up to date activities.

Based on the results of the multiple linear regression analysis, the hypothesis stating that the more attractive photos and videos are, the effectiveness of Instagram as a promotion media for Bhumi 
Merapi Agrotourism will be higher is accepted. This is because visitors get an interesting impression on photos/videos that are posted through Bhumi Merapi Agrotourism Instagram account. Visitors like the photos that contain the joy of being at the location and are very memorable for the photos of children who dare to hold various reptiles under the supervision of a guide. However, the number of videos on the agrotourism Instagram account is still few with a ratio of 1: 10 or there is 1 video among 10 photos. The video posted on September 19 contained videos of outbound activities and field trips at SD N Tegalrejo 01. This small number of video postings is due to the long process of video editing.

In accordance with the results of research that has been done, photos/ videos have an attraction with a value of $75.72 \%$ in the category 'agree'. The attractiveness of photos/ videos is fundamental in carrying out promotions through Instagram. This is because the Instagram feature emphasizes more on photo and video posts and limits the number of characters in the caption to explain the posted photos / videos. In addition, the attractiveness of clear photos (not shaking or blur when taking photos), attractive captions, as well as appropriate photos and explanations will add to the attractiveness of photos / videos on Instagram Bhumi Merapi Agrotourism Yogyakarta. Therefore, the more interesting the photos/ videos that are posted, the higher the effectiveness of Instagram as a promotional medium will be.

The attractiveness of photos/ videos is related to promotion (social marketing). The fundamental difference between commercial promotion and social marketing is partnerships and policies that affect the behavior and interests of the wider community for consideration. The results of the suitability of photos with captions as an indicator of photo/ video attractiveness have high results so that they can be improved or maintained. One of the improvements can be done by making an interesting caption containing an educational message and an invitation to visit Bhumi Merapi Agrotourism. The elements of agricultural extension can be carried out by agrotourism with promotion through Bhumi Merapi Agrotourism Instagram. Messages containing agricultural education, photos of activities during field trips, hydroponic training, or other touring activities can be an educational process for visitors who access Bhumi Merapi Agrotourism Instagram.

The results of this study are in line with the results of research conducted by (Kurniawan, 2015) who found that the attractiveness of photos/ videos had an effect on the effectiveness of Instagram as a promotional medium. A promotion carried out on Instagram social media is designed to attract the attention of consumers so that they will dig deeper information and end up making a decision to enjoy a product/ service being promoted. Photos and videos on Instagram are the most effective media that can be used in attracting the attention of visitors because these are the tools that become prominent icons in Instagram social media. In addition, photos and videos as audio-visual media are more effective than media that rely on audio or text only. The attractiveness of the photo was also pointed out by (Sari et al., 2019) where tourist photos uploaded on social media, whether they are aware of it or not, are able to provide information, causing an attraction to the stage of action on those who see it. Travel photos serve as a medium that bridges potential tourists with tourist attractions whose photos are uploaded on social media.

\section{CONCLUSION}

The effectiveness of Bhumi Merapi Agrotourism promotion through Instagram is high. Based on the proportion test, the results obtained were $82.31 \%$, meaning that visitors considered the promotion of Bhumi Merapi Agrotourism through Instagram was classified as very effective. The factors that influence the effectiveness of Bhumi Merapi Agro tourism promotion through Instagram include: visitors' perception and photo/ video attractiveness. Meanwhile, the factors that do not affect include: age, frequency of use of Instagram, completeness of information.

Bhumi Merapi Agrotourism manager needs to increase promotion by posting photos/ videos that represent the location or activities of Bhumi Merapi Agrotourism in a clear, good quality, captions that match the photos/ videos and persuasive captions that invite to visit Bhumi Merapi Agrotourism in Yogyakarta. Bhumi Merapi Agrotourism manager needs to improve the quality of agrotourism Instagram by posting photos/ videos that display outbound activities by including $5 \mathrm{~W}+1 \mathrm{H}$ information in the caption. Bhumi Merapi Agrotourism manager needs to increase information on agrotourism Instagram through posting photos/ videos that display tour package information for visitors by including the price for each package. 


\section{6}

\section{REFERENCES}

Anwar, T. M. (2019). Phenomenology of Communication of Generation Z in Pekanbaru. Komunikator, 11(1). https://doi.org/10.18196/jkm.111015

Budiarti, T., \& Muflikhati, I. (2013). Pengembangan Agrowisata Berbasis Masyarakat Pada Usahatani Terpadu Guna Meningkatkan Kesejahteraan Petani Dan Keberlanjutan Sistem Pertanian. Jurnal Ilmu Pertanian Indonesia, 18(3), 200-207.

Cangara, H. (2009). Pengantar Ilmu Komunikasi. Jakarta: PT. Raja Grafindo Persada.

Fadhila, A. P., Wastutingsih, S. P., \& Untari, D. W. (2017). Keefektifan Official Weblog Sebagai Media Promosi Desa Wisata Salak Pondoh Pulesari Kecamatan Turi Kabupaten Sleman. Berkala Ilmiah AGRIDEVINA, 6(1), 55-70.

Junaedi, I. W. R., \& Utama, I. G. B. R. (2017). Agrotourism As the Economics Transformation of the Tourism Village in Bali (Case Study: Blimbingsari Village, Jembrana, Bali). Journal of Business on Hospitality and Tourism, 2(1), 10. https://doi.org/10.22334/jbhost.v2i1.37

Kurniawan, H. (2015). Efektivitas Media Sosial Instagram Sebagai Media Promosi Batik Solo “ Inasinul ."

Kurniyati, N. E., \& Rahmawati, D. (2018). Persepsi Wisatawan Terhadap Akun Media Sosial Instagram@Watuamben. Media Wisata, 16(1), 757-766.

Kusumastuti, Y. I. (2009). Komunikasi Bisnis. Bogor: IPB Press.

Lestari, N., Amanah, S., Muljono, P., \& Susanto, D. (2019). Pengaruh Profil Petani Pengelola Agrowisata terhadap Kapasitas Pemanfaatan Teknologi Komunikasi Digital di Kabupaten Bojonegoro dan Malang, Provinsi Jawa Timur. AGRARIS: Journal of Agribusiness and Rural Development Research, 5(1). https://doi.org/10.18196/agr.5176

Mahendra, B. (2017). Eksistensi Sosial Remaja Dalam Instagram (Sebuah Perspektif Komunikasi). Jurnal Visi Komunikasi, 16(1), 151-160. https://doi.org/10.22441/jvk.v16i1.1649

Malkanthi, S., \& Routry, J. (2011). Potential for agritourism development: Evedance from Sri Lanka. Journal of Agricultural Sciences, 6(1), 45. https://doi.org/10.4038/jas.v6i1.3812

Marlina, L., Saleh, A., \& Lumintang, R. (2009). Perbandingan Efektivitas Media Cetak (Folder Dan Poster-Kalender) Dan Penyajian Tanaman Zodia Terhadap Peningkatan Pengetahuan $\begin{array}{llll}\text { Masyarakat. Jurnal Komunikasi } & \text { Pembangunan, } & \text { 7(2), }\end{array}$ https://doi.org/10.29244/jurnalkmp.7.2.

Rangkuti, F. (2009). Strategi Promosi yang Kreatif dan Analisis Kasus Integrated Marketing Communication,.

Sadono, D. (2008). Pemberdayaan Petani: Paradigma Baru Penyuluhan Pertanian di Indonesia. Jurnal Penyuluhan, 4(1). https://doi.org/10.25015/penyuluhan.v4i1.2170

Saputri, R. D., Anantanyu, S., \& Wijanto, A. (2016). Perkembangan Kelompok Tani di Kabupaten Sukoharjo. 4(3).

Sari, P. E., Mariyanti, E., \& Putri, S. L. (2019). Pengaruh Electronic Word Of Mouth Foto Wisata terhadap Keputusan Berkunjung Wisatawan di Padang. Manajemen Dan Kewirausahaan, 10(1), 22. https://doi.org/10.31317/jmk.10.1.22-37.2019

Sari ZA, A. F., Sari, N. P., \& Nabila, N. (2019). Promosi Kesehatan "Sadari” Menggunakan Instagram pada Mahasiswi Non Kesehatan Universitas Andalas. Media Kesehatan Masyarakat Indonesia, 15(3), 253. https://doi.org/10.30597/mkmi.v15i3.6270

Supradono, B., \& Hanum, A. N. (2011). Peran Sosial Media Untuk Manajemen Hubungan Dengan Pelanggan Pada Layanan E-Commerce. Unimus, $7(2), \quad 33$. https://doi.org/10.1016/j.cyto.2015.08.063

Watie, E. D. S. (2016). Komunikasi dan Media Sosial (Communications and Social Media). Jurnal The Messenger, 3(2), 69. https://doi.org/10.26623/themessenger.v3i2.270

Yani, diarsi eka. (2009). persepsi anggota terhadap peran kelompok tani pada penerapan teknologi usahatani BELIMBING (Kasus Kelompok Tani Kelurahan Pasir Putih , Kecamatan Sawangan, Kota Depok). 